\title{
PENGEMBANGAN MODEL PEMBELAJAAN BERBASIS PROJEK \\ PENDIDIKAN KEWIRAUSAHAAN UNTUK MENINGKATKAN SIKAP, MINAT, PERILAKU WIRAUSAHA, DAN PRESTASI BELAJAR SISWA SMK
}

\author{
Endang Mulyani \\ Fakultas Ekonomi Universitas Negeri Yogyakarta \\ email: endangmulyani_uny@yahoo.com
}

\begin{abstract}
Abstrak: Tujuan penelitian untuk: (1) mengembangkan model pembelajaran berbasis proyek pendidikan kewirausahaan; dan (2) mengetahui efektivitas model pembelajaran dalam upaya meningkatkan kemampuan nonakademik (sikap, minat, perilaku wirausaha), dan kemampuan akademik siswa SMK. Pengembangan model dengan menggunakan Four-D model meliputi tahap define, design, develop, dan disseminate. Rancangan model dalam penelitian ini hanya sampai pada tahap ketiga. Subjek penelitian adalah siswa kelas XI Program Keahlian Penjualan, guru ekonomi, dan guru kewirusahaan. Pengumpulan data lewat angket, dokumentasi, dan observasi, sedang analisis data dengan teknik deskriptif dan Multivariate Analysis of Covariance (Mancova). Hasil penelitian ini menunjukkan: (1) tersedianya model hipotetik pembelajaran berbasis proyek pendidikan kewirausahaan yang layak digunakan di di SMK; dan (2) model yang diterapkan dalam kelas eksperimen lebih efektif untuk meningkatkan sikap kewirausahan, minat berwirausaha, dan prestasi belajar, namun dalam hal meningkatkan perilaku kewirusahaan model yang diterapkan di kelompok kontrol dan eksperimen tidak berbeda efektivitasnya.
\end{abstract}

Kata Kunci: model pembelajaran, pembelajaran berbais proyek, pendidikan kewirausahaan

\section{DEVELOPING AN ENTERPRENEURSHIP EDUCATION PROJECT-BASED LEARNING MODEL TO IMPROVE THE ENTREPRENEURIAL ATTITUDES, INTERESTS, BEHAVIOR AND ACADEMICACHIEVEMENT OF STUDENTS IN VOCATIONAL SECONDARY SCHOOLS}

\begin{abstract}
The aims of this study were: (1) to develop an entrepreneurship education project-based learning model; and (2) to know the effectiveness of the learning model to improve non- academic skills (the entrepreneurial attitudes, interests, behavior) and the academic achievement of students in vocational secondary schools. This study used the Four-D model, consisting of define, design, develop, and disseminate stages. The model in this study did not take the disseminate stage; it only took the first three stages. The research subjects comprised Year XI students of the sales study program, economics teachers, and entrepreneurship teachers. The data were collected through questionnaires, documents, and observations. The data were analyzed using the descriptive analysis technique and the Multivariate Analysis of Variance (Manova). The findings were: (1) the availability of a hypothetic entrepreneurship education project-based learning model which was suitable to be used in vocational secondary schools; (2) that the hypothetic entrepreneurship education project-based learning model implemented in theexperimental class was more effective to improve entrepreneurial attitude, interests, and academic achievement. However, there was no significant difference in the entrepreneurial behavior between the experimental class and the control class.
\end{abstract}

Keywords: learning model, entrepreneurship education project-based, vocational secondary schools

\section{PENDAHULUAN}

Dalam UU Nomor 20 Tahun 2003 tentang Sistem Pendidikan Nasional pada Pasal 3 disebutkan bahwa tujuan pendidikan nasional adalah untuk mengembangkan potensi peserta didik agar menjadi manusia yang beriman dan bertakwa kepada Tuhan Yang Maha Esa, berakhlak mulia, sehat, berilmu, cakap, kreatif, mandiri, dan menjadi warga negara yang demokratis serta bertanggung jawab. Untuk melihat ketercapaian tujuan pendidikan dapat dilihat dari indikator ketercapaian tujuan penyelenggaraan 
dan hasil pendidikan. Terdapat beberapa indikator yang dapat digunakan untuk mengetahui ketercapaian tujuan pendidikan. Indikator tersebut disebut indikator mutu hasil pendidikan. Indikator mutu hasil pendidikan yang selama ini digunakan di antaranya adalah nilai Ujian Nasional, persentase kelulusan, angka drop out, angka mengulang kelas, dan persentase lulusan yang melanjutkan ke jenjang pendidikan di atasnya. Indikator-indikator tersebut cenderung bersifat kuantitatif. Di samping indikator kuantitatif, indikator mutu hasil pendidikan lainnya yang sangat penting untuk dicapai adalah indikator kualitatif yang meliputi beriman dan bertakwa kepada Tuhan Yang Maha Esa, berakhlak mulia, sehat, berilmu, cakap, kreatif, mandiri, dan menjadi warga negara yang demokratis serta bertanggung jawab. Indikator kualitatif tersebut berkaitan dengan pembentukan karakter peserta didik dan pembentukan sikap serta keterampilan/skill peserta didik sehingga mampu bersaing, beretika, bermoral, sopan santun, memiliki sikap dan keterampilan/skill, termasuk keterampilan berwirausaha. Drucker (1996) mengatakan bahwa wirausaha selalu mencari perubahan, menanggapinya dan memanfaatkannya sebagai peluang. Konsep inilah yang harus dijabarkan ke dalam indikator kualitatif.

Ketercapaian tujuan pendidikan nasional, terutama yang mengarah pada pembentukan sikap, minat, dan perilaku wirausaha peserta didik di SMK, selama ini belum dapat diketahui secara pasti. Hal ini mengingat pengukurannya cenderung bersifat kualitatif, dan belum ada standar nasional untuk menilainya. Selain belum adanya standar nasional untuk mengukur sikap, minat dan perilaku wirausaha, permasalahan yang lain adalah bahwa pendidikan kewirausahaan di Indonesia masih kurang memperoleh perhatian yang cukup memadai, baik oleh dunia pendidikan maupun masyarakat. Banyak pendidik yang kurang memperhatikan penumbuhan sikap, minat, dan perilaku wirausaha peserta didik, baik di Sekolah menengah Kejuruan (SMK) maupun di pendidikan profesional.

Pengamatan di SMK N I Depok pada penelitian pendahuluan menunjukkan bahwa dilihat dari model pembelajaran yang dilakukan di SMKN I Depok masih cenderung menggunakan metode ceramah dan masih cenderung ke arah kognitif. Hasil belajar diukur dari nilai hasil ulangan harian, ulangan tengah semester, dan ujian akhir semester. Selain itu, model penilaian/assessment yang digunakan di SMK belum mampu menilai keberhasilan tujuan pembelajaran yang mampu mengukur sikap, minat, dan perilaku wirausaha secara utuh. Hal ini menyebabkan keberhasilan dari tujuan pembelajaran yang terkait dengan kemampuan kewirausahaan belum dapat diketahui secara pasti. Oleh karena itu, untuk mengatasi permasalahan tersebut perlu dikembangkan model pembelajaran berbasis projek pendidikan kewirausahaan yang mampu menumbuhkan prestasi belajar dalam bidang akademik yang mencakup aspek kognitif, afektif, dan psikomotorik. Selain itu, juga mampu menumbuhkan kemampuan kewirausahaan yang meliputi sikap, minat dan perilaku wirausaha.

Pembelajaran berbasis projek menawarkan manfaat yang sangat luas bagi para siswa dan guru. Menurut Waras Kamdi (20018), Pembelajaran Berbasis Proyek (Project-Based Learning) adalah model pembelajaran yang menggunakan proyek/kegiatan sebagai proses pembelajaran untuk mencapai kompetensi sikap, pengetahuan dan keterampilan. Projek yang digunakan dalam penelitian ini adalah projek pendidikan kewirausahaan.

Kewirausahaan (entrepreneurship) muncul apabila seseorang individu berani mengembangkan usaha-usaha dan ide-ide barunya. Proses kewirausahaan meliputi semua fungsi, aktivitas, dan tindakan yang berhubungan dengan perolehan peluang dan penciptaan organisasi usaha (Suryana, 2001).

Meredith (2006) memberikan ciri-ciri seseorang yang memiliki jiwa wirausaha (entrepeneur) sebagai orang yang (1) percaya diri; (2) berorientasi tugas dan hasil; (3) berani mengambil risiko; (4) berjiwa kepemimpinan; (5) berorientasi ke depan; dan (6) keorisinal.

Manfaat pelajaran berbasis projek seperti berikut. (1) Meningkatkan kehadiran, menumbuhkan kepercayaan diri, dan memperbaiki sikap melalui belajar (Thomas, J.W., 1998). ( 2) 
Keuntungan akademik seimbang dengan atau lebih baik dari mereka yang menggunakan model lain, dan para siswa yang terlibat dalam projek-projek mempunyai tanggung jawab yang lebih besar terhadap cara belajar mereka sendiri dibandingkan dengan aktivitas kelas yang lebih tradisional. (3) Kesempatan untuk mengembangkan kemampuan kompleks, seperti pola berpikir susunan tinggi, pemecahan masalah, berkolaborasi, dan berkomunikasi. (4) Akses terhadap peluang belajar yang lebih luas di dalam kelas, memberikan sebuah strategi untuk melibatkan pelajar dengan beragam budaya (Railsback, J. 2002).

\section{METODE}

Pengembangan model dalam penelitian ini mengikuti prosedur pengembangan (Thiaragajan, Semmel \& Semmel, 1974) yang dikenal dengan Four-D model. Tahap-tahap Four-D model meliputi tahap define, design, develop, dan desseminate. Langkah pertama dalam Four$D$ model adalah (define). Kegiatan dalam tahap pertama ini adalah melakukan kajian awal yang meliputi analisis kurikulum, teori model pembelajaran, analisis materi, karakteristik siswa, dan identifikasi model pembelajaran yang digunakan di SMK. Pada tahap design, dilakukan pengembangan format model. Tahap develop, dilakukan pengembangan model hipotetik dan uji coba sampai diperoleh master model, dan tahap terakhir adalah tahap desseminate. Rancangan model dalam penelitian ini belum sampai pada tahap desseminate, hanya meliputi tiga tahap, yaitu tahap define (pendefinisian), design (perancangan), dan develop (pengembangan).

Alur pengembangan model pembelajaran berbasis proyek pendidikan kewirausahaan terintegrasi di SMK tampak pada Gambar 1.

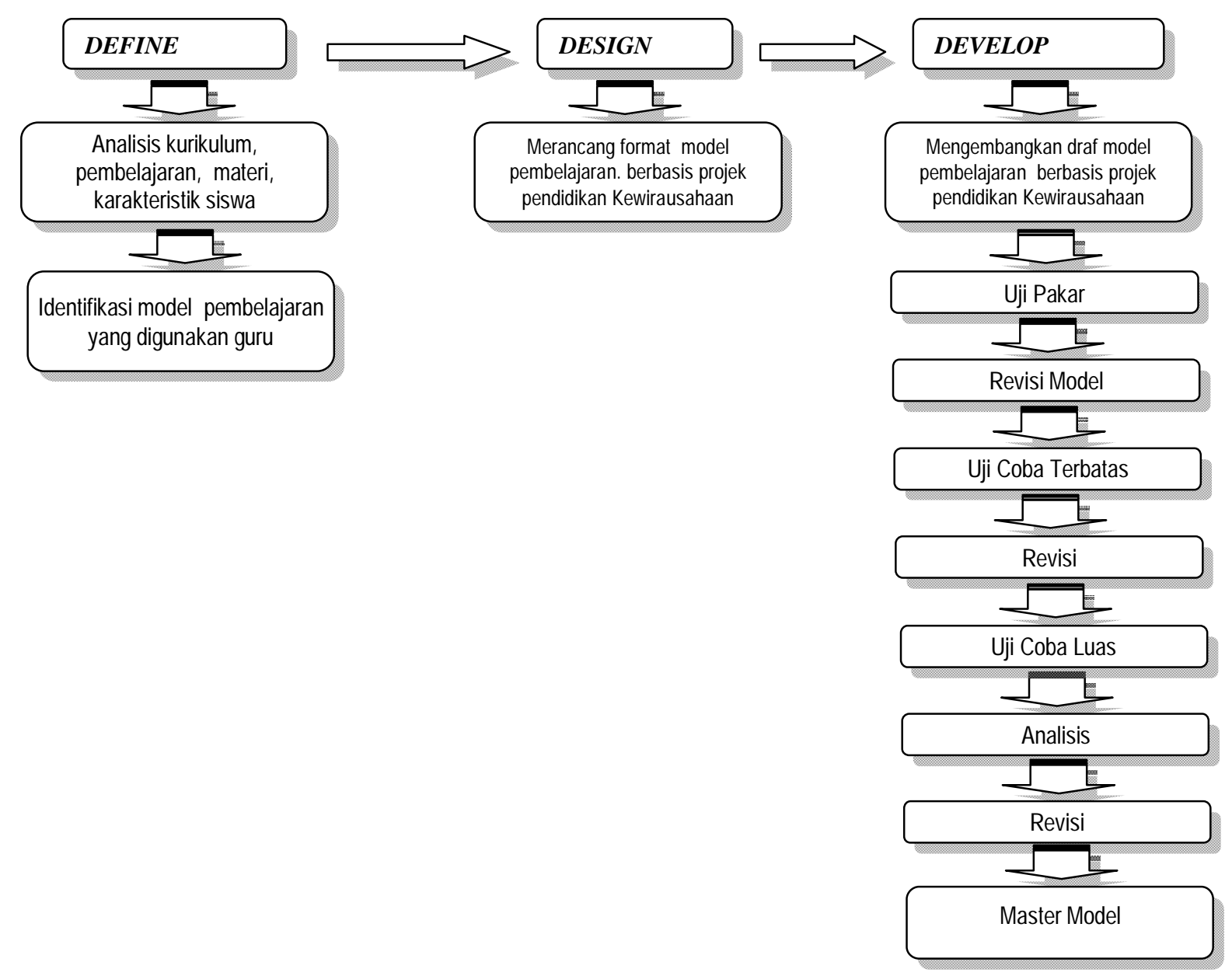

Gambar 1. Alur Pengembangan Model Pembelajaran Berbasis Projek Pendidikan Kewirausahaan 


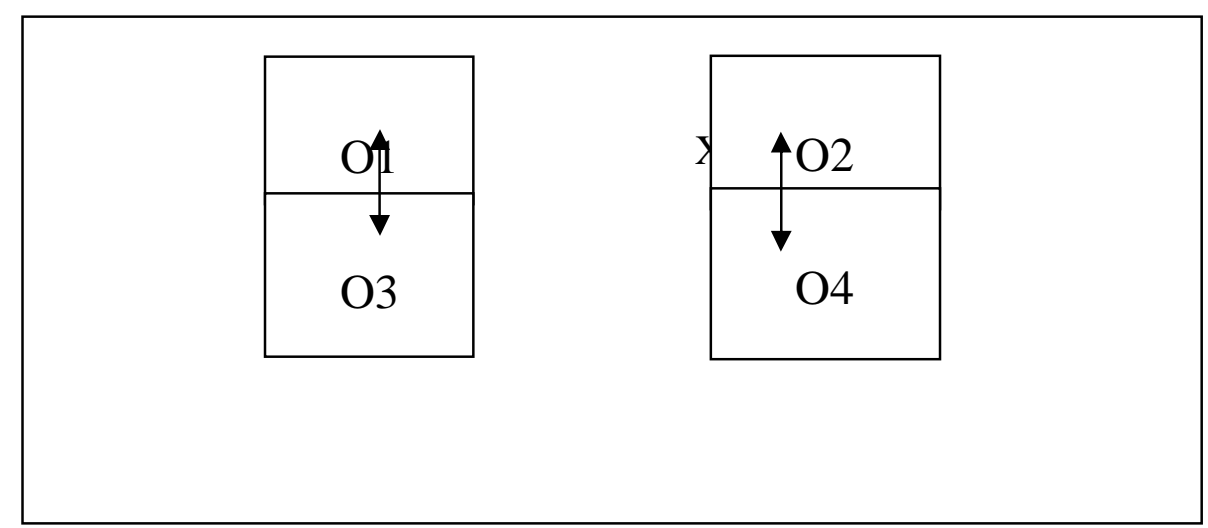

\section{Gambar 2. Desain Kelompok Eksperimen dengan Kelompok Kontrol (Pretest-Postest Control Group Desain )}

Keterangan:

O1: nilai awal kelompok eksperimen

O3: nilai awal kelompok kontrol

O2: nilai kelompok eksperimen setelah ada intervensi model penilaian

O4: nilai kelompok kontrol tidak ada intervensi model penilaian/penilaian konvensional (Sugiyono, 2008: 416).

Variabel dalam penelitian ini terdiri atas variabel model pembelajaran berbasis projek pendidikan kewirausahaan, kemampuan non akademik (sikap, minat dan perilaku wirausaha) serta kemampuan akademik (pretasi belajar).

Uji coba model dilakukan di SMKN I Depok Sleman Yogyakarta. Uji coba dilakukan dengan metode eksperimen dengan model pretest-postest control group desain. Model eksperimen ini dapat dilihat pada Gambar 2.

Subjek untuk uji coba adalah guru dan siswa SMK N I Depok kelas XI. Guru yang terlibat sebagai subjek uji coba adalah satu guru Ekonomi dan satu guru Kewirausahaan yang mengajar di kelas 2 (kelas XI). Siswa yang terlibat dalam penelitian ini adalah sebanyak dua kelas.

Teknik pengumpulan data yang digunakan dalam penelitian ini adalah teknik dokumentasi, angket, dan observasi. Dokumentasi digunakan untuk memperoleh data tentang hal-hal yang berkaitan dengan data siswa dan guru. Metode angket digunakan untuk mengungkap data mengenai variabel sikap, minat, dan perilaku wirausaha siswa SMK. Observasi digunakan untuk mengumpulkan data mengenai aktivitas belajar siswa selama pembelajaran berlangsung.
Untuk keperluan pengembangan model tersebut, disusunlah beberapa instrumen seperti berikut.

- Instrumen penilaian pakar tentang model pembelajaran berbasis projek pendidikan kewirausahaan.

- Instrumen penilaian pakar tentang pengembangan instrumen penilaian pembelajaran berbasis projek pendidikan kewirausahaan.

- Instrumen keterlaksanaan model pembelajaran berbasis projek pendidikan kewirausahaan.

- Instrumen tentang sikap, minat, dan perilaku wirausaha.

- Instrumen penilaian angket sikap siswa terhadap wirausaha

- Instrumen penilaian angket minat siswa terhadap wirausaha.

- Instrumen penilaian angket perilaku wirausaha.

- Instrumen penilaian rubrik.

- Instrumen untuk mengungkap faktor pendukung dan penghambat penerapan model pembelajaran berbasis projek pendidikan kewirausahaan.

Teknik analisis berupa teknik analisis diskriptif yang digunakan untuk menganalisis variabel berikut. (1) Sikap, minat, dan perilaku 
wirausaha siswa. (2) Mengetahui perubahan sikap, minat dan perilaku wirausaha sebelum dan sesudah ada intervensi penerapan model pembelajaran berbasis projek pendidikan kewirausahaan. Selanjutnya, digunakan teknik analisis Mancova. Teknik analisis Mancova digunakan untuk mengetahui perbedaan sikap, minat, dan perilaku wirausaha serta prestasi belajar antara siswa yang diberi intervensi model pembelajaran berbasis projek pendidikan kewirausahaan dan yang tidak diberi intervensi model pembelajaran berbasis projek pendidikan kewirausahaan.

\section{HASIL DAN PEMBAHASAN}

\section{Pengembangan Model Pembelajaran Berba- sis Projek Pendidikan Kewirausahaan}

Pembelajaran berbasis projek (PBP) merupakan salah satu model pembelajaran inovatif. PBP berfokus pada konsep dan prinsip inti sebuah disiplin, memfasilitasi siswa untuk berinvestigasi, pemecahan masalah, dan tugas-tugas bermakna lainnya, student centered, dan menghasilkan produk nyata. Dalam Pembelajaran Berbasis Proyek (PBP), projek dilakukan secara kolaboratif dan inovatif, unik, berfokus pada pemecahan masalah yang berhubungan dengan kehidupan siswa atau kebutuhan masyarakat atau industri lokal. Pada pembelajaran berbasis projek dalam penelitian ini, projek dirancang yang terkait dengan penumbuhan nilainilai kewirausahaan. Kelebihan PBP adalah dapat membuat pengalaman belajar menjadi lebih menarik dan bermakna bagi siswa dan mahasiswa. Dalam PBP, siswa menjadi terdorong lebih aktif dalam belajar, guru hanya sebagai fasilitator, guru mengevaluasi produk hasil kinerja siswa yang meliputi outcome yang mampu ditampilkan dari hasil proyek yang dikerjakan.

Pada saat siswa mengerjakan tugas proyek, mereka dapat berkolaborasi dengan satu atau dua orang guru. Siswa juga melakukan investigasi dalam kelompok kolaboratif antara 45 orang. Keterampilan-keterampilan yang dibutuhkan dan dikembangkan oleh siswa dalam tim adalah merencanakan, mengorganisasikan, negosiasi, dan membuat konsensus tentang tugas yang dikerjakan, siapa yang mengerjakan apa, dan bagaimana mengumpulkan informasi yang dibutuhkan dalam berinvestigasi.

Alur pembelajaran komprehensif berbasis proyek pendidikan kewirausahaan teintegrasi di SMK dapat dilihat pada Gambar 3.

Alur pembelajaran komprehenshif berbasis projek pendidikan kewirausahaan dalam penelitian ini dapat dijelaskan sebagai berikut. Pembelajaran ini mengacu pada KTSP yang sudah dikembangkan di SMK. KTSP dikembangkan dengan dasar Standar Isi (SI) dan Standar Kompetensi Lulusan (SKL). KTSP terdiri dari dua dokumen, yaitu dokumen satu dan dokumen dua. Dalam penelitian ini, difokuskan pada pengembangan dokumen dua, yaitu berupa silabus dan RPP. Silabus dan RPP dikembangkan mengacu pada Standar Kompetensi dan Kompetensi Dasar, kemudian dikembangkan indikator dan tujuan pembelajaran yang masing-masing diintegrasikan dengan ciri-ciri wirausaha. Langkah selanjutnya adalah merancang pembelajaran berbasis projek pendidikan kewirausahaan. Setelah merancang pembelajaran berbasis projek pendidikan kewirausahaan, kemudian disusun skenario pembelajaran yang meliputi pembelajaran di kelas, di luar kelas, dan di laboratorium yang dilaksanakan di Bussiness Center. Langkah selanjutnya adalah menyusun perangkat pembelajaran yang berupa Silabus dan RPP yang digunakan sebagai pedoman dalam pelaksanaan pembelajaran.

Penerapan pembelajaran tersebut mampu meningkatkan prestasi belajar di bidang akademik (meliputi aspek kognitif, afektif dan psikomotorik), serta mampu mengembangkan sikap, minat dan perilaku wirausaha siswa SMK. Dengan demikian, penerapan model pembelajaran komprehensif berbasis proyek pendidikan kewirausahaan terintegrasi di SMK tersebut diharapkan mampu meningkatkan prestasi belajar di bidang akademik (meliputi aspek kognitif, afektif dan psikomotorik), serta mampu menumbuhkan sikap, minat dan perilaku wirausaha siswa SMK. Temuan ini sesuai dengan hasil penelitian Bransford, Brown, \& Conking yang menyatakan bahwa kemampuan siswa untuk memperoleh pemahaman baru akan meningkat ketika mereka terhubung dengan aktivitas pemecahan 
masalah yang penting, dan ketika para siswa dibantu untuk memahami mengapa, kapan, dan bagaimana fakta-fakta dan kemampuan saling terkait (Bransford, Brown, \& Conking, 2000: 23).

\section{Efektivitas Model Pembelajaran Berbasis Proyek Pendidikan Kewirausahaan}

Pengujian efektivitas model pembelajaran berbasis projek pendidikan kewirausahaan di SMK untuk masing-masing kelompok dilakukan dengan menggunakan uji Mancova (Multivariate Analysis of Covariance). Dalam uji Mancova pretest dijadikan sebagai kovariat. Penggunaan pre-test sebagai kovariat dimaksudkan agar pengaruhnya pada nilai post-test dapat dikendalikan. Dengan analisis ini, diperoleh perbedaan nilai post-test antara kelompok eksperi- men dan kelompok kontrol. Hal tersebut dilakukan untuk menjamin validitas internal dari eksperimen ini. Nilai pre-test perlu digunakan sebagai kontrol agar nilai post-test yang diuji benar-benar merupakan nilai murni yang sudah tidak dipengaruhi lagi oleh nilai pre-test. Hal ini didasarkan pada pertimbangan bahwa nilai pretest dapat mempengaruhi hasil post-tes karena kemungkinan subjek penelitian dapat mengingat kembali jawaban-jawaban yang salah pada waktu pre-test, dan kemudian pada waktu posttest subjek tersebut dapat memperbaiki jawabannya. Oleh sebab itu, perubahan variabel terikat tersebut bukan karena hasil eksperimen saja, tetapi juga karena pengaruh dari pre-test. Sebelum dilakukan uji Mancova perlu dilakukan pengujian persyaratan analisis seperti berikut.

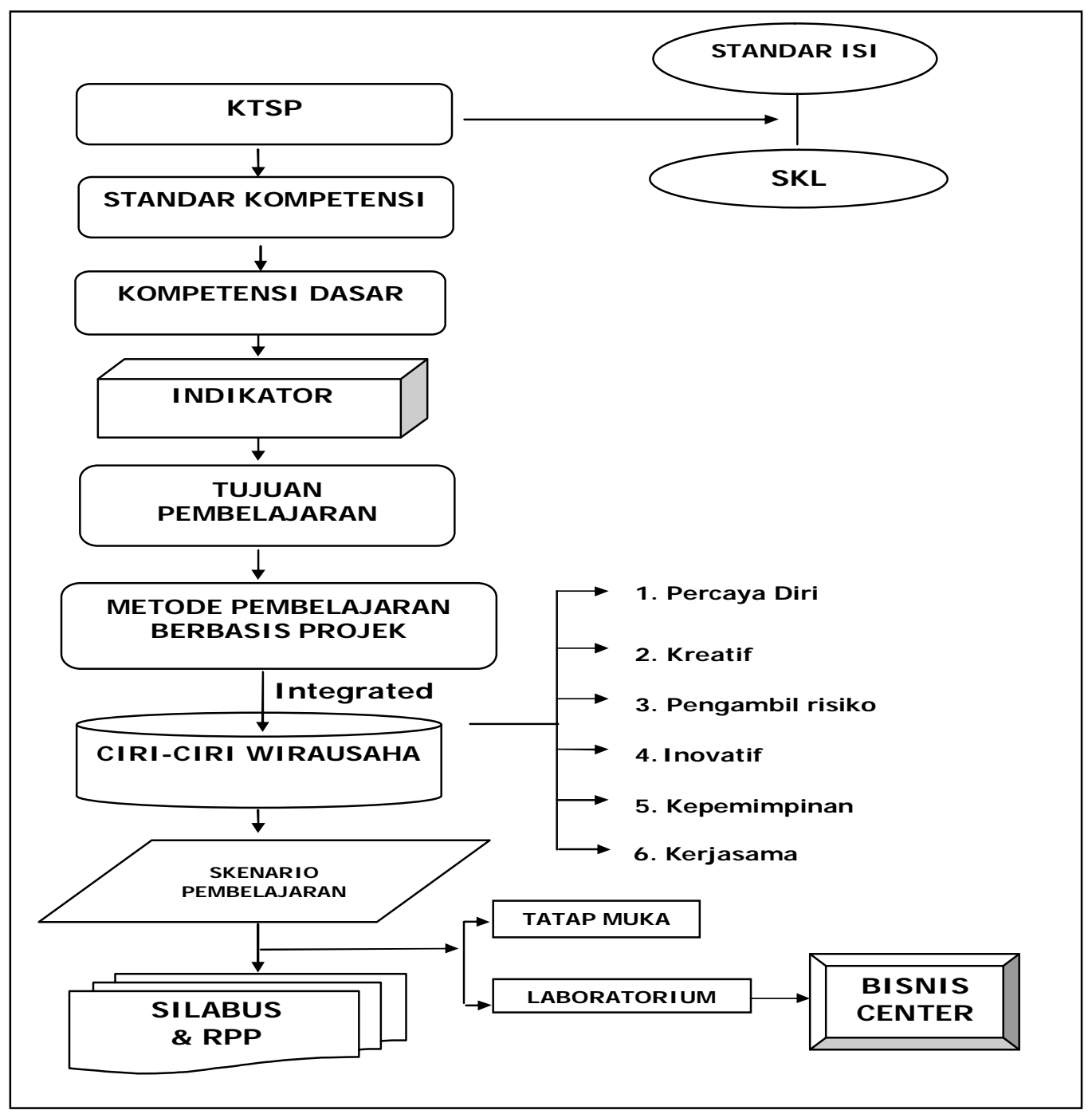

Gambar 2. Alur Pembelajaran Berbasis Projek Pendidikan Kewirausahaan 


\section{Uji Persyaratan Analisis}

- Normalitas Sebaran Data pada Uji Coba Terbatas

Pengujian normalitas sebaran data dilakukan dengan menggunakan teknik analisis Kolmogorov-Smirnov. Kriteria pengujian menggunakan taraf signifikansi 5\%. Artinya, jika nilai $\mathrm{p}$ yang ditemukan lebih dari atau sama dengan 0,05 , data berdistribusi normal, tetapi jika nilai $\mathrm{p}$ kurang dari 0,05 , data tidak berdistribusi normal.

\section{- Uji Homogenitas Kovarians pada Uji Coba} Terbatas

Penggunaan analisis Mancova memerlukan persyaratan bahwa matriks kovarians dari seluruh variabel dependen antarkelas harus bersifat homogen. Pengujian dilakukan dengan menggunakan uji Box's M. Hasil analisis uji homogenitas kovarians menunjukkan bahwa setelah perlakuan diperoleh nilai koefisien Box'M = 16,289, $\mathrm{F}=1,528$ dan nilai $p=0,122$ (di atas 0,05 ). Dengan demikian, dapat disimpulkan bahwa ada kesamaan matriks kovarians untuk variabel sikap kewirausahaan, minat berwirausaha, perilaku kewirausahaan, dan kemampuan akademik.

\section{- Uji Homosedastisitas}

Penggunaan analisis Mancova juga memerlukan persyaratan bahwa varians dari seluruh variabel dependen antarkelas harus bersifat homogen. Pengujian homogenitas varians dilakukan dengan menggunakan uji Levene. Berdasarkan hasil analisis di atas, ditemukan bahwa seluruh nilai $\mathrm{p}$ melebihi 0,05. Dengan demikian, dapat disimpulkan bahwa varians antarkelas (kontrol dan eksperimen) untuk seluruh variabel yang diteliti bersifat homogen. Jadi, seluruh persyaratan yang harus dipenuhi sehubungan dengan penggunaan analisis Mancova telah terpenuhi. Setelah persyaratan analisis terpenuhi, langkah selanjutnya dilakukan uji efektivitas model untuk masing-masing kelompok. Berikut akan dipaparkan hasil uji efektivitas masing-masing kelompok.
Uji Efektivitas Model Pembelajaran Berbasis Proyek Pendidikan Kewirausahaan Kelas Kontrol

Pengujian efektivitas model pembelajaran di kelas kontrol dilakukan dengan menggunakan uji Paired t-test. Hasil uji efektivitas model pembelajaran kelas kontrol (menggunakan pembelajaran konvensional/ceramah) dapat dilihat pada Tabel 1. Untuk mempermudah pemahaman, hasil analisis yang dipaparkan pada Tabel 1 dapat digambarkan dalam bentuk Grafik 1. Berdasarkan Tabel 1 dan Grafik 1, dapat dijelaskan hal-hal sebagai berikut.

- Skor post-test sikap kewirausahaan lebih tinggi dibandingkan dengan skor pre-test. Hasil analisis menunjukkan bahwa rerata skor pretest untuk sikap kewirausahaan adalah sebesar 97,16, sedangkan rerata posttest sebesar 97,73. Berdasarkan hasil pengujian, ditemukan bahwa nilai $\mathrm{t}$ sebesar $-0,849$ dengan $p=0,401$. Karena nilai $p$ tersebut lebih besar dari 0,05, dapat disimpulkan bahwa nilai post-test sikap kewirausahaan siswa tidak lebih baik dari skor pre-test. Dengan demikian, dapat dikatakan bahwa pelaksanaan model penilaian komprehensif berbasis proyek pendidikan kewirausahaan terintegrasi di SMK di kelas kontrol tidak efektif untuk meningkatkan sikap kewirausahaan siswa.

- Skor post-test minat berwirausaha lebih tinggi dibandingkan dengan skor pre-test. Hasil analisis menunjukkan bahwa rerata skor pretest untuk minat berwirausaha adalah sebesar 92,49, sedangkan rerata post-test sebesar 94,95. Berdasarkan hasil pengujian, ditemukan bahwa nilai $\mathrm{t}$ sebesar $-2,745$ dengan $\mathrm{p}=$ 0,009 . Karena nilai $\mathrm{p}$ tersebut kurang dari 0,05 , dapat disimpulkan bahwa nilai posttest minat berwirausaha siswa lebih baik daripada skor pre-test. Dengan demikian, dapat dikatakan di kelas kontrol yang diterapkan di kelompok kontrol efektif untuk meningkatkan minat berwirausaha siswa. 
Tabel 1. Efektivitas Model Pembelajaran Berbasis Projek Pendidikan Kewirausahaan di Kelas Kontrol

\begin{tabular}{clrrrr}
\hline \multirow{2}{*}{ No } & \multicolumn{1}{c}{ Variabel } & \multicolumn{2}{c}{ Skor Rata-rata } & \multirow{2}{*}{ T } & \multirow{2}{*}{ P } \\
\cline { 3 - 4 } & & Pre test & Post Test & & \\
\hline 1. & Sikap Kewirausahaan & 97.16 & 97.73 & -.849 & .401 \\
2. & Minat Berwirausaha & 92.49 & 94.95 & -2.745 & .009 \\
3. & Perilaku Kewirausahaan & 112.78 & 113.27 & -.644 & .524 \\
4. & Kemampuan Akademik (Prestasi belajar) & 70.40 & 75.45 & -4.710 & .000 \\
\hline
\end{tabular}

Sumber: Data primer yang diolah

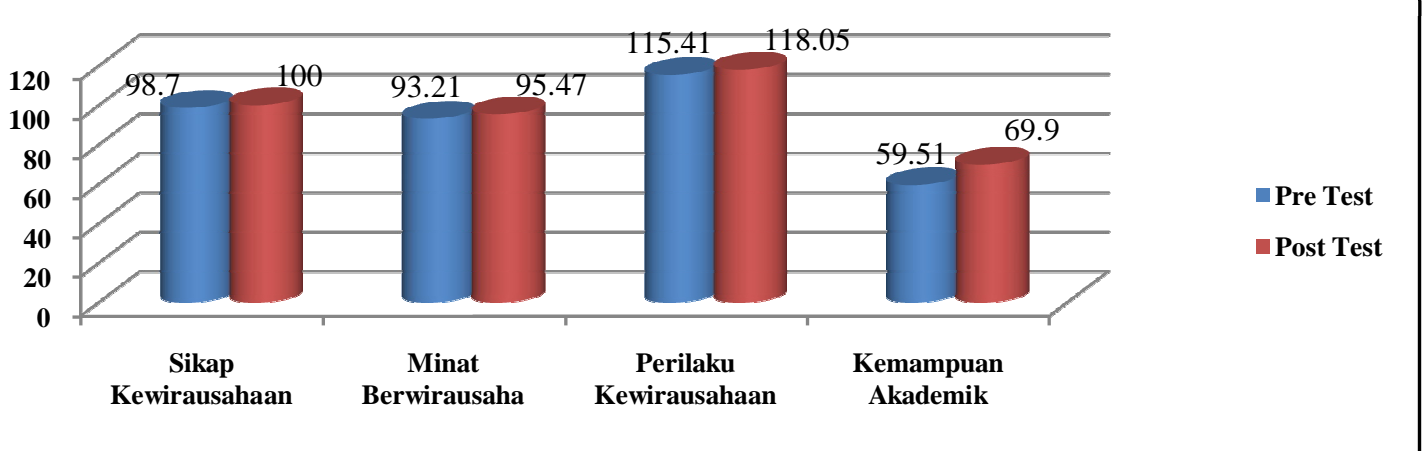

Grafik 1. Hasil Pre-test dan Post-test Kemampuan Akademik (Sikap, Minat, dan Perilaku Wirausaha) serta Kemampuan Akademik (Prestasi Belajar Siswa)

- Skor post-test perilaku kewirausahaan lebih tinggi dibandingkan dengan skor pre-test. Hasil analisis menunjukkan bahwa rerata skor pre-test untuk perilaku kewirausahaan adalah sebesar 1152,78, sedangkan rerata posttest sebesar 113,27. Berdasarkan hasil pengujian, ditemukan nilai t sebesar $-0,644$ dengan $p=0,524$. Karena nilai $p$ tersebut lebih dari 0,05 , dapat disimpulkan bahwa nilai post-test perilaku kewirausahaan siswa tidak lebih baik daripada skor pre-test. Dengan demikian, dapat dikatakan bahwa pelaksanaan model penilaian komprehensif berbasis proyek pendidikan kewirausahaan terintegrasi di SMK kelas kontrol tidak efektif untuk meningkatkan perilaku kewirausahaan siswa.

- Skor post-test prestasi belajar lebih tinggi dibandingkan dengan skor pre-test. Hasil analisis menunjukkan bahwa rerata skor pre-test untuk kompetensi akademik sebesar 70,40, sedangkan rerata post-testnya sebesar 75,45.
Berdasarkan hasil pengujian, ditemukan bahwa nilai $\mathrm{t}$ sebesar $-4,710$ dengan $\mathrm{p}=$ 0,000 . Karena nilai $\mathrm{p}$ tersebut kurang dari 0,05 , maka dapat disimpulkan bahwa nilai post-test kemampuan akademik lebih baik daripada skor pre-est. Berdasarkan hasil pengujian di atas, dapat ditarik kesimpulan bahwa model penilaian yang di kelas kontrol mampu meningkatkan minat berwirausaha dan kemampuan akademik siswa.

\section{Uji Efektivitas Model Pembelajaran Berbasis Proyek Pendidikan Kewirausahaan Kelas Eksperimen}

Hasil uji analisis pelaksanaan model pembelajaran berbasis proyek pendidikan kewirausahaan di kelas ekperimen dapat dilihat pada Tabel 2. Untuk mempermudah pemahaman, hasil analisis yang dipaparkan pada Tabel 1 dapat digambarkan dalam bentuk Grafik 1 . 
Tabel 2. Hasil Uji Efektivitas Model Pembelajaran Berbasis Projek Pendidikan Kewirausahaan Kelas Eksperimen

\begin{tabular}{|c|c|c|c|c|c|}
\hline \multirow{2}{*}{ No } & \multirow{2}{*}{ Variabel } & \multicolumn{2}{|c|}{ Skor Rata-rata } & \multirow{2}{*}{$\mathbf{T}$} & \multirow{2}{*}{$\mathbf{P}$} \\
\hline & & Pre-test & Post-test & & \\
\hline 1. & Sikap Kewirausahaan & 100.69 & 108.29 & -6.633 & .001 \\
\hline 2. & Minat Berwirausaha & 93.80 & 99.51 & -5.185 & .001 \\
\hline 3. & Perilaku Kewirausahaan & 117.46 & 120.29 & -3.696 & .001 \\
\hline 4. & Kemampuan Akademik & 71.19 & 78.23 & -5.723 & .001 \\
\hline
\end{tabular}

Sumber: Data pimer yang diolah

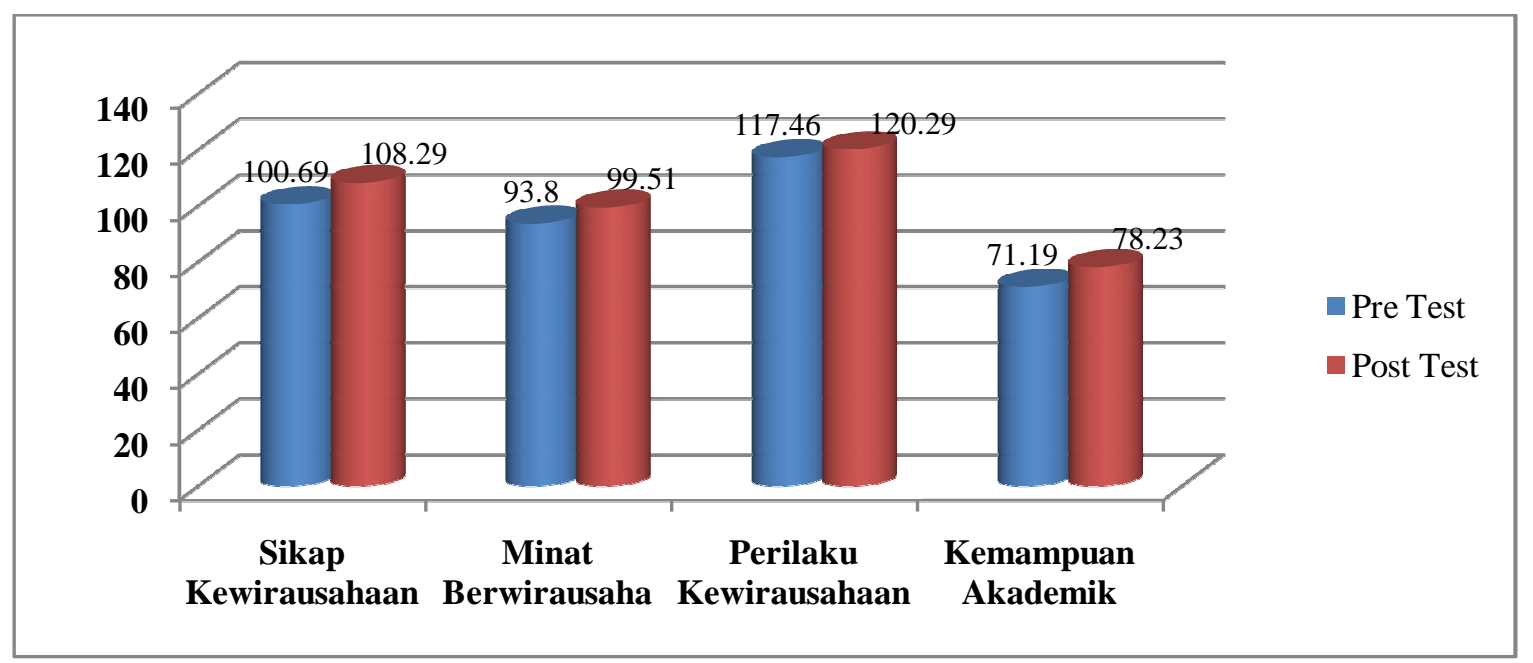

\section{Grafik 2. Hasil Pre-test dan Post-test Sikap, Minat, Perilaku Kewirausahaan, dan Prestasi Belajar Kelas Eksperimen}

Tabel 3. Perbedaan Efektivitas Model Penilaian di Kelas Kontrol dan Kelas Eksperimen

\begin{tabular}{llrrrr}
\hline \multirow{2}{*}{ No } & \multicolumn{1}{c}{ Variabel } & \multicolumn{2}{c}{ Kelas } & \multirow{2}{*}{$\begin{array}{c}\text { F Wilks } \\
\text { Lambda }\end{array}$} & \multirow{2}{*}{ P } \\
\cline { 3 - 4 } & & Eksperimen & Kontrol & 13,332 & 0,000 \\
\hline 1. & Sikap Kewirausahaan & 108,29 & 97,73 & & \\
2. & Minat Berwirausaha & 99,51 & 94,95 & & \\
3. & Perilaku Kewirausahaan & 120,29 & 113,27 & & \\
4. & Kemampuan Akademik & 78,23 & 75,45 & & \\
& (prestasi belajar) & & & & \\
\hline
\end{tabular}

Sumber: Data primer yang diolah

Berdasarkan Tabel 2 dan Grafik 2 di atas, dapat dijelaskan sebagai berikut.

- Skor post-test sikap kewirausahaan lebih tinggi dibandingkan dengan skor pre-test. Hasil analisis menunjukkan bahwa rerata skor pre-test untuk sikap kewirausahaan sebesar 100,69, sedangkan rerata post-testnya sebesar 108,29. Berdasarkan hasil pengujian, ditemukan nilai bahwa t sebesar $-6,633$ dengan $p=0,000$. Karena nilai $p$ tersebut kurang dari 0,05 , dapat disimpulkan bahwa nilai post-test sikap kewirausahaan siswa lebih baik daripada skor pre-test. Dengan demikian, dapat dikatakan bahwa model pembelajaran yang diterapkan di kelas eksperimen efektif untuk meningkatkan sikap kewirausahaan siswa.

- Skor post-test minat berwirausaha lebih tinggi dibandingkan dengan skor pre-test. Hasil analisis menunjukkan bahwa rerata skor pretest untuk minat berwirausaha sebesar 93,80, sedangkan rerata post-test sebesar 99,51. Berdasarkan hasil pengujian, ditemukan nilai $t$ sebesar $-5,185$ dengan $p=0,000$. Ka- 
rena nilai $\mathrm{p}$ tersebut kurang dari 0,05 , dapat disimpulkan bahwa nilai post-test minat berwirausaha siswa lebih baik daripada nilai pre-test. Dengan demikian, dapat dikatakan bahwa model pembelajaran berbasis proyek pendidikan kewirausahaan yang diterapkan di kelas eksperimen efektif untuk meningkatkan minat berwirausaha siswa.

- Skor post-test perilaku kewirausahaan lebih tinggi dibandingkan dengan skor pre-test. Hasil analisis menunjukkan bahwa rerata skor pre-test untuk perilaku kewirausahaan sebesar 117,46, sedangkan rerata post-test sebesar 120,29. Berdasarkan hasil pengujian, ditemukan nilai $\mathrm{t}$ sebesar $-3,696$ dengan $\mathrm{p}=$ 0,001 . Karena nilai $\mathrm{p}$ tersebut kurang dari 0,05 , dapat disimpulkan bahwa skor posttest perilaku kewirausahaan siswa lebih baik daripada skor pre-test. Dengan demikian, dapat dikatakan bahwa model pembelajaran berbasis proyek pendidikan kewirausahaan yang diterapkan di kelas eksperimen efektif untuk meningkatkan perilaku kewirausahaan siswa.

- Skor post-test kemampuan akademik aspek kognitif lebih tinggi dibandingkan dengan skor pre-test. Hasil analisis menunjukkan bahwa rerata skor pre-test untuk kemampuan akademik aspek kognitif adalah sebesar 71,19 , sedangkan rerata post-test sebesar 78,23 . Berdasarkan hasil pengujian, ditemukan bahwa nilai $\mathrm{t}$ sebesar $-5,723$ dengan $\mathrm{p}=$ 0,000 . Karena nilai $\mathrm{p}$ tersebut kurang dari 0,05 , dapat disimpulkan bahwa nilai posttest kemampuan akademik aspek kognitif lebih baik daripada skor pre-test.

Berdasarkan hasil pengujian di atas, dapat disimpulkan bahwa model pembelajaran berbasis proyek pendidikan kewirausahaan yang diterapkan di kelas eksperimen mampu meningkatkan sikap kewirausahaan, minat berwirausaha, perilaku kewirausahaan, dan prestasi belajar siswa. Karena kedua model pembelajaran tersebut sama-sama efektif dalam meningkatkan variabel sikap kewirausahaan, minat berwirausaha, dan prestasi belajaran, maka perlu diuji perbedaan efektivitas untuk kedua model pembelajaran berikut.

\section{Perbedaan Efektivitas Model Pembe- lajaran berbasis Projek Pendidikan Ke- wirausahaan di Kelas Kontrol dan Kelas Eksperimen}

Untuk melihat efektivitas implementasi model pembelajaran di kelas kontrol dengan kelas eksperimen dilakukan uji Mancova. Hasil pengujian tersebut dapat dilihat pada Tabel 3.

Tabel 3 menunjukkan bahwa pada saat post-test terlihat bahwa nilai $\mathrm{F}$ yang ditemukan sebesar 13,332 dengan $\mathrm{p}<0,05$. Dengan demikian, dapat disimpulkan bahwa secara keseluruhan terdapat perbedaan rerata skor antara kelas eksperimen dan kelas kontrol. Karena hasilnya signifikan, perlu dilihat variabel mana saja yang secara signifikan berbeda, seperti uraian berikut.

- Sikap kewirausahaan kelas eksperimen lebih baik dibandingkan dengan kelas kontrol. Hasil pengujian pada tabel di atas, menunjukkan bahwa nilai rerata sikap kewirausahaan kelas eksperimen sebesar 108,29, sedangkan rerata kelompok kontrol sebesar 97,73. Hasil pengujian $\mathrm{F}$ ditemukan sebesar 39,858 dengan $\mathrm{p}<05$. Jadi, dapat disimpulkan bahwa model pembelajaran berbasis proyek pendidikan kewirausahaan yang diterapkan dalam kelas eksperimen lebih efektif dalam meningkatkan sikap kewirausahaan siswa dibandingkan dengan yang diterapkan pada kelas kontrol.

- Minat berwirausaha kelas eksperimen lebih baik dibandingkan dengan kelas kontrol. Hasil pengujian pada tabel di atas, menunjukkan bahwa nilai rerata minat berwirausaha kelas eksperimen sebesar 99,51, sedangkan rerata kelas kontrol sebesar 94,95. Hasil pengujian F ditemukan sebesar 7,139 dengan $\mathrm{p}<05$. Dengan demikian, dapat dikatakan bahwa minat berwirausaha kelas eksperimen terbukti lebih baik dibandingkan minat berwirausaha kelas kontrol.

- Perilaku kewirausahaan kelas eksperimen lebih baik dibandingkan dengan kelas kontrol. Hasil pengujian di atas menunjukkan bahwa nilai rerata perilaku kewirausahaan kelas eksperimen sebesar 120,29, sedangkan rerata kelas kontrol sebesar 118,27. Hasil 
pengujian $\mathrm{F}$ ditemukan sebesar 1,461 dengan nilai $\mathrm{p}>05$. Jadi, dapat disimpulkan bahwa model pembelajaran berbasis proyek pendidikan kewirausahaan yang diterapkan dalam kelas eksperimen tidak lebih efektif dalam meningkatkan perilaku kewirausahaan siswa dibandingkan dengan yang diterapkan pada kelas kontrol.

- Prestasi belajar akademik kelas eksperimen lebih baik dibandingkan dengan kelas kontrol. Hasil pengujian di atas menunjukkan bahwa nilai rerata kemampuan akademik kelas eksperimen sebesar 78,23, sedangkan rerata kelas kontrol sebesar 75,45. Hasil pengujian $\mathrm{F}$ ditemukan sebesar 5,290 dengan $\mathrm{p}<$ 05. Jadi, dapat disimpulkan bahwa model pembelajaran berbasis proyek pendidikan kewirausahaan yang diterapkan dalam kelas eksperimen lebih efektif dalam meningkatkan kemampuan akademik siswa dibandingkan dengan yang diterapkan pada kelas kontrol. Hasil ini sesuai dengan penelitian yang dilakukan Thomas tentang cara belajar berbasis proyek menyimpulkan bahwa sebuah proyek yang berfokus pada pertanyaan atau soal yang mengarahkan para siswa untuk menghadapi (dan berjuang keras untuk mengatasi) konsep-konsep sentral dan prinsip-prinsip ilmu pengetahuan (Thomas, 2000:3).

\section{PENUTUP}

Berdasarkan hasil analisis data dan pembahasan dapat disimpulkan beberapa hal seperti berikut.

- Telah dikembangkan model hipotetik pembelajaran berbasis projek pendidikan kewirausahaan.

- Terdapat peningkatan sikap, minat, dan perilaku wirausaha siswa SMK setelah diberi intervensi model pembelajaran komprehenshif berbasis proyek pendidikan kewirausahaan. Hasil analisis menunjukkan bahwa berdasarkan nilai rata-rata pre-test, dapat diketahui bahwa variabel sikap, minat, dan perilaku wirausaha pada kelas eksperimen dan kelas kontrol mempunyai perbedaan yang tidak begitu besar. Setelah penerapan model penilaian komprensif berbasis proyek pendidikan kewirausahaan, nilai rata-rata yang diperoleh cenderung lebih besar kelas eksperimen atau kelas yang mendapatkan tindakan. Nilai perbedaan rata-rata yang paling besar terdapat pada sikap terhadap wirausaha, yaitu sebesar 0.28 , dan minat terhadap wirausaha sebesar 0.12 .

- Dilihat dari uji perbedaan efektivitas model pembelajaran yang diterapkan di kelas kontrol dan model pembelajaran yang diterapkan di kelas eksperimen dengan menggunakan Manova, dapat ditarik kesimpulan bahwa model pembelajaran yang diterapkan dalam kelas eksperimen ternyata lebih efektif untuk meningkatkan sikap kewirausahaan, minat berwirausaha, dan prestasi belajar. Namun, dalam hal meningkatkan perilaku kewirausahaan model yang diterapkan di kelompok kontrol dan eksperimen tidak berbeda efektivitasnya.

\section{UCAPAN TERIMA KASIH}

Terima kasih kami ucapkan kepada Redaktur dan Staf Jurnal Cakrawala Pendidikan Universitas Negeri Yogyakarta yang telah memberi tuang bagi terbitnya artikel ini.

\section{DAFTAR PUSTAKA}

Departemen Pendidikan Nasional. 2003. Undang-Undang Nomor 20 Tahun 2003 tentang Sistem Pendidikan Nasional. Jakarta: Depdiknas.

Drucker, Peter F. 1996. Inovasi dan Kewiraswastaan: Praktek dan Dasar-Dasar. Jakarta: Erlangga.

Khamdi, Waras. "Project Based Learning: Pendekatan Pembelajaran Inovatif'. $M a$ kalah yang disampaikan dalam Pelatihan Penyusunan Bahan Ajar Guru SMP dan SMA Kota Tarakan, 31 Oktober s.d. 2 November 2008.

Meredith, George. 2002. Kewirausahaan Teori dan Praktek. Jakarta: PPM. 
Railsback, J. 2002. Project-Based Instruction: Creating Excitement for Learning. Portland, OR: Northwest Regional Educational Laboratory. http://www.nwrel.org/request/2002aug/index.html*.

Suryana. 2006. Kewirausahaan Pedoman Praktis: Kiat dan Proses Menuju Sukses. Bandung: PT Salemba Empat.
Thiaragajan, S., Semmel, D. S., \& Semmel, M. L. 1974. Instructional Development for Training Teachers of Exceptional Children. Minnesota: Indiana University.

Thomas, J.W. 1998. "Project-Based Learning: Overview". Novato, CA: Buck Institute for Education. Journal of Nursing Education. Vol. 38, Iss.8, pg. 340, 7 pgs. 